\title{
Corporate governance reforms and management control
}

\author{
Carl-Christian Freidank • Toomas Haldma • \\ Patrick Velte
}

This special issue of the Journal of Management Control focuses on the impact of corporate governance reforms on management control. Under the term of "corporate governance", reform approaches, primarily from a legal point of view, are discussed and transformed into standards, to manage companies more efficiently and control them more effectively. In two tier systems (e.g., in Germany or Austria), corporate governance in public limited companies is primarily aimed at the rights and responsibilities of the management board, supervisory board and shareholder's meeting, which sustain the target-oriented management and control of the company. However, also in one tier systems (e.g., in the UK or USA), corporate governance has a central significance. The bundling of management and control tasks for inside and outside directors based on the board system admittedly provides a flexible allocation of powers and responsibilities, however, at the same time, contains risks with reference to the neutrality of management control. After the last financial crisis, several corporate governance reforms, e.g., in the European Union, have substantially changed the management control practice of companies.

Keeping these aspects in mind, it is a great pleasure for us to introduce this special issue with three papers by six German researchers and one US researcher. The main topics of the following issue are the economic role of audit committees, say on pay

\footnotetext{
C.-C. Freidank $(\bowtie)$

University of Hamburg, Hamburg, Germany

e-mail: CarlChristian.Freidank@wiso.uni-hamburg.de

T. Haldma

University of Tartu, Tartu, Estonia

P. Velte

Leuphana University, Luneburg, Germany
} 
voting and integrated reporting which are subject to current regulation discussions from a national and international view.

The implementation of audit committees is a key aspect of "good" corporate governance with regard to the accounting and audit quality of listed stock corporations. In order to supervise the reporting process and cooperate with the external auditor, audit committees intensively deal with the management board's compliance with the law and usefulness of the accounting practices. Nevertheless, the monitoring of accounting activities is part of the supervisory board's plenum tasks in two tier systems. Several corporate governance reforms, e.g., the US-American Sarbanes Oxley Act (SOX) 2002 or the new European audit regulation 2014, stress the importance of audit committees with independent members and financial experts. The paper of Mahfuja Malik gives a detailed literature review of audit committee composition and effectiveness in the post-SOX era. The researchers have investigated new research issues that are mostly driven by SOX, which include the role of the audit committee in the firms' internal control weaknesses, the role of financial accounting experts in limiting misreporting and market reactions to the appointment of experts. The analysis shows that also other issues that were not addressed by SOX are focused, e.g., audit committee compensation and the social ties of committee members with the chief executive officer as well as the supervision or other expertise of audit committee members.

Another regulation instrument for increased corporate governance quality is discussed by the term "say on pay", which includes shareholder rights to vote on the management remuneration. The classical principal agent theory concludes that directors are likely to overpay themselves. Proponents argue that say on pay-regulation strengthen the relationship between the board of directors and shareholders, ensuring that board members fulfill their fiduciary duty. Opponents claim that say on pay will not generally lead to lower and sustainable management compensation. There is a controversial political discussion now whether voluntary say on pay rules (e.g., in Germany) or mandatory rules (e.g., in the USA) are suitable to increase corporate governance quality. In two tier systems, e.g., in Germany, the supervisory board is responsible for the management compensation system, so that voting rights of the shareholders can lead to new competence problems. Marc Eulerich, Jochen Theis and Artur Kalinichenko investigate the voluntary usage of say on pay in 290 German Prime Standard companies for the general meeting seasons 2011-2013 and compare the results to respective data for the season 2010. They examine the influence of corporate performance and corporate governance characteristics on say on pay. The regression analysis shows that the likelihood for the occurrence of a vote increases with company size and decreases with growing free float. Finally, they find a positive link between companies' leverage ratio and say on pay voting likelihood.

Other great reform activities dwell on the development of modern business reporting. The value reporting discussion has been updated in the last years through corporate governance reporting and integrated reporting. After the last financial market crisis, a short-dated shareholder value policy has been mainly criticized. The consequence of these failures was the implementation of corporate social responsibility reporting (CSR) and sustainable management remuneration systems. To lower the risk of information overload, the International Integrated Reporting Council (IIRC) has published an "Integrated Reporting Framework" in 2013 to connect the traditional financial 
accounting and CSR reporting. Integrated reporting provides relevant information for valuation purposes so that all stakeholders can have an improved idea as to the estimation of the company's value. In Germany, many companies integrate CSR as part of the management commentary. The paper of Inge Wulf, Jens Niemöller and Natalia Rentzsch evaluates the ability of an integrated report to improve corporate governance quality in comparison to the management commentary. They analyze similarities and differences between the German management commentary and the integrated report with respect to corporate governance reporting topics in the German Corporate Governance Code (GCGC). The authors state that an integrated report is better suited to improve corporate governance quality in comparison to the management commentary.

We would like to thank our authors and reviewers for their great work and hope that you will enjoy this special issue. In the light of the dynamic development of corporate governance regulation we also hope that his special issue makes a clear contribution to future research interactions between corporate governance and management control. 